\title{
WAYS TO OVERCOME THE CRISIS CONDITION OF THE UKRAINIAN INSURANCE MARKET: THE ECONOMIC AND LEGAL ASPECT
}

\author{
Olga Poberezhets ${ }^{1}$, Tetiana Stepanova ${ }^{2}$ \\ Odesa I.I. Mechnikov National University, Ukraine \\ Roman Shchur ${ }^{3}$ \\ Vasyl Stefanyk Precarpathian National University, Ukraine
}

\begin{abstract}
Trends of the integration of the insurance market on European and world scale make it necessary to examine the insurance sector of the economy. As a result of the financial and economic crisis, all financial and economic instruments of states covered negative phenomena. The current stage of development of the national and world economy is described by the uneven overcoming of the crisis in different sectors of the economy that negatively affects integration processes. As in Ukraine the insurance sphere has not received due attention and support from the state, the formation of an appropriate basis for overcoming the crisis phenomena in the insurance sector of the economy, the application of which is a condition for further development and use of potential opportunities for improving economic systems, determines the timeliness of consideration of this issue. In the course of overcoming the crisis phenomena in the insurance sphere, a critical combination of deterrents arises, the systematization and research of which helps in developing actions to overcome the crisis in the insurance sector of the economy, which determines a necessity of complex examination of this problem with the goal of an early exit from the crisis and further integration of insurance markets. The purpose of the article is to consider internal and external factors that delay the way out of the crisis of the insurance market, and on the basis of generalizing the deterrents of development - providing recommendations of the systematization of actions to overcome the crisis of the insurance sector, taking into account features of the national and global insurance market. Methodology. Analytical market reviews, materials of periodicals, resources of the Internet are the informational and methodological basis of the investigation. To achieve the goal set, the following general scientific and special methods were used: economic and mathematical methods, structural-logical analysis, analogy, synthesis, comparison and integration, factor analysis. Results. The system of actions of economic and legal nature that should be taken into account for successfully overcoming the crisis of the insurance sphere is substantiated. Problem aspects of external and internal nature and directions of their elimination are determined. The proposed model for overcoming the crisis of the insurance sphere takes on special significance in the context of the supranational task of developing actions to minimize and eliminate the consequences of the global economic crisis. Directions for reforming the regulatory and legislative basis are considered. Practical implications. The system of economic and legal actions and their separate types can be applied for the successful overcoming of the crisis in the insurance sector, taking into account the specifics of economic development and the condition of the insurance sector of the economy in other countries. Value/originality. Most of the scientific studies are devoted to the theoretical aspects of the economic crisis, namely, the more precise definition of the essence of this process as a form of modern financial and economic dynamics. A part of the studies is devoted to the consideration of common features and national features of the economic crisis in individual countries and regions. The authors considered the issues of developing actions to overcome the crisis in the insurance sphere in a system combining the abovementioned aspects with the specifics of development and overcoming the crisis moments of the insurance sector of the economy. It is also important to take into account the influence of planned legislative reforms on the development of the insurance market in Ukraine. Accounting for all components of the insurance market, existing features within the confines of the national economy has allowed us to work out directions for further development of the insurance market.
\end{abstract}

Key words: insurance, insurance market, crisis condition, economic development, economic and legal regulation, risk.

JEL Classification: G22, K22

\footnotetext{
Corresponding author:

${ }^{1}$ Department of Economic and Management, Odesa I.I. Mechnikov National University.

E-mail: olga-poberezhec@ukr.net

${ }^{2}$ Department of Administrative and Commercial Law, Odesa I.I. Mechnikov National University.

E-mail: stepanovatv@ukr.net

${ }^{3}$ Department of Finance, Vasyl Stefanyk Precarpathian National University.

E-mail: romanwur@ukr.net
} 


\section{Introduction}

The political redistribution of spheres of influence on the world map and the clash of interests of superpowers inevitably led to economic cataclysms on an international scale. Ukraine experienced several "waves" of financial and economic crisis, particularly in 2008 and 2014 However, in the insurance sector, crisis phenomena appear much longer than, for example, in the banking sector. The problem of the economic crisis has ceased to be a problem of individual states and has become a global problem; therefore, the development of actions to minimize and eliminate the consequences of the global economic crisis has become a supranational task.

Restructuring of the Ukrainian economy resulted in an exacerbation of the risk situation with a simultaneous lack of conditions for the development of demand for insurance coverage. There are a number of grounds for that. First of all, unfortunately, today the demographic situation in Ukraine and the low level of the population's insurance culture significantly hamper the development of the insurance sector of the economy. Secondly, the lack of socialization of capital has changed the insurance programs, transferring them mainly to the rank of tax minimization tools. Finally, participation in the globalization and integration of the insurance market is not always effective and safe for insurance operators, although in the final version it will ensure the formation of a global insurance space.

So, there are several areas of the insurance sector of the economy naturally appeared, requiring immediate and in-depth research and development of a system of anti-crisis measures.

Theoretical foundations and practical issues of the development and systematization of actions to overcome the crisis of the insurance sector are considered in the works of many native and foreign authors, including recently raised the problem in their works by G. Cherednichenko, A. Chukhno, A. Gritsenko, A. Zadoya, I. Maliy, T. Mironov, and others. However, it should be noted that to date, there has not been a unified approach to solving this problem.

\section{Insurance as an important component of the development of the real sector of the economy}

In the world rating "Doing Business 2017" (Doing Business, 2017) rightly noted that "Trade processes involve not only government authorities and private firms but also customs brokers, commercial banks, vendors, insurance companies, and freight forwarders."

Over the past year, many players left the Ukrainian insurance market: in the second quarter of 2017, 307 companies had licenses for insurance activities, a year earlier - 356, and two years ago - more than 400. As of December 31, 2017, according to data of the National Commission implementing state regulation in the sphere of financial services markets, which is the state regulator of insurance services in Ukraine, there were also registered 64 non-state pension funds, 56 insurance and reinsurance brokers, 50 actuaries with corresponding certificates, 304 emergency commissioners (Forinsurer, 2018).

The structure of the Ukrainian insurance market differs from the European one: in the EU countries, for example, life insurance is $50-70 \%$ of all premiums, and in Ukraine, it varies at the level of $6-8 \%$ of the total volume of the insurance services market. Risk insurance directly depends on the general economic situation in the country. By the results of the first half of 2017 for insurance of corporate clients following the growth is minimal $-5.9 \%$ : the volumes of insurance of cargo luggage, property against fire risks, agrarian risks, minimal growth in MTPL (motor third party liability) insurance, property insurance - decreased (Delo.ua, 2018).

Total assets of insurers grew by $2.3 \%$ to 57.4 billion UAH. As of December 31, 2017, insurance reserves increased by $9.2 \%$ (Forinsurer, 2018).

Thus, we can conclude that the insurance market is gradually increasing, albeit with minimal showings. At the same time, insurance is traditionally like an "airbag" for the population and business entities, while providing jobs and expanding and strengthening the real sector of the Ukrainian economy, helps to overcome the crisis phenomena that occurred in Ukraine.

\section{Factors of the development of the insurance market}

Managing the process of overcoming the crisis should combine an organic combination of economic growth and financial stabilization with an active social policy that seeks to raise the standards of living of the population and its effective demand. Thus, development factors of the insurance market in Ukraine include: the level of material security of the population (the average level of wages, pensions, benefits, scholarships, and other payments); the development of competition and the abandonment of the market monopoly; introduction of new technologies; entry into international insurance markets; the level of the crime situation in the country; development and improvement of the domestic legislation of Ukraine and its adaptation to the legislation of the European Union and the world community; financial and economic stability of the country; high insurance culture of the population, restoration of confidence in the insurance industry; the existence of a targeted state policy for the development of insurance; a clear system of state control over the financial reliability of insurers; presence of investment in entrepreneurial activity.

Among the factors in the development of the insurance market, an increase in the equity capital of insurance companies and an increase in the volume of insurance payments for the year should also be noticed.

Analysis of the TOP-20 rating of insurance companies in terms of equity capital for 2017 (Table 1) compared 
with 2016 shows that only 9 of them had a positive growth rate, and in the bulk - a small (1.9-16.24\%), with the exception of IC Credo (No. 11 rating), which had a positive growth rate of $142,69 \%$.

If we analyse the TOP-20 rating of insurance companies by the size of insurance payments for 2017
(Table 2), we will see that in comparison with 2016 they all give a positive trend, but their distribution in the rating is significantly different.

Thus, IC "Kremen", which occupies a leading position in the rating of insurance companies by the size of its equity capital, takes only 13 th place in the rating of

Table 1

Rating of insurance companies by the size of equity capital for 2017

\begin{tabular}{|c|l|c|c|c|}
\hline \multirow{2}{*}{$N$} & \multicolumn{1}{|c|}{ Insurance companies } & $\begin{array}{c}\text { Equity capital 2017, } \\
\text { thousand UAH }\end{array}$ & $\begin{array}{c}\text { Equity capital 2017, } \\
\text { thousand UAH }\end{array}$ & Rate, \% \\
\hline 1 & KREMEN & 1999491,8 & 2010012,9 & $-0,52$ \\
\hline 2 & ALLIANCE & 1317786,0 & 1323583,0 & $-0,44$ \\
\hline 3 & INGO UKRAINE & 640996,4 & 612897,9 & $-18,28$ \\
\hline 4 & OMEGA & 497199,4 & 608386,4 & $-19,73$ \\
\hline 5 & AXA INSURANCE & 488402,0 & 608453,0 & 16,24 \\
\hline 6 & TAS IG & 450208,1 & 387297,1 & 2,83 \\
\hline 7 & UNIQA & 415530,0 & 404098,0 & 9,97 \\
\hline 8 & UKRAINIAN INSURANCE GROUP & 291571,6 & 265142,4 & $-39,63$ \\
\hline 9 & PROVIDNA & 281298,0 & 465949,0 & 6,39 \\
\hline 10 & ARSENAL INSURANCE & 273904,0 & 257464,0 & 142,69 \\
\hline 11 & CREDO & 273443,0 & 112674,0 & 11,90 \\
\hline 12 & UNIVERSAL & 272161,0 & 267095,0 & $-7,22$ \\
\hline 13 & PZU UKRAINE & 265452,0 & 238795,0 & $-3,41$ \\
\hline 14 & UPSK & 261731,3 & 282097,0 & $-32,56$ \\
\hline 15 & ORANTA & 253030,3 & 261970,1 & $-35,89$ \\
\hline 16 & ZAHID-REZERV & 246785,0 & 365906,0 & 2,22 \\
\hline 17 & MOTOR-GARANT & 240640,0 & 375357,0 & $-3,13$ \\
\hline 18 & TECOM & 232916,0 & 227867,0 & 4,88 \\
\hline 19 & MEGA-GARANT & 201868,2 & 208383,2 & 182780,0 \\
\hline 20 & PROSTO-INSURANCE & 191691,0 & & \\
\hline
\end{tabular}

Source: systematized by the authors (Forinsurer, 2018)

Table 2

Rating of insurance companies by the size of insurance payments for 2017

\begin{tabular}{|c|l|c|c|}
\hline № & \multicolumn{1}{|c|}{ Insurance companies } & Payments 2017, thousand UAH & Payments 2016, thousand UAH \\
\hline 1 & AXA INSURANCE & 817672,0 & 601896,0 \\
\hline 2 & UNIQA & 617101,0 & 382183,0 \\
\hline 3 & INGO UKRAINE & 549711,5 & 387696,6 \\
\hline 4 & PROVIDNA & 484330,5 & 314406,0 \\
\hline 5 & PZU UKRAINE & 453769,7 & 321085,4 \\
\hline 6 & UKRAINIAN INSURANCE GROUP & 385143,0 & 262223,6 \\
\hline 7 & TAS IG & 371336,8 & 243454,2 \\
\hline 8 & ARSENAL INSURANCE & 323475,0 & 185766,5 \\
\hline 9 & KNYAZHA & 243398,1 & 149940,3 \\
\hline 10 & ORANTA & 195469,1 & 92791,0 \\
\hline 11 & ASKA & 188366,0 & 163904,1 \\
\hline 12 & NEFTEGAZSTRAH & 185927,0 & 42531,8 \\
\hline 13 & KREMEN & 171082,9 & 104052,6 \\
\hline 14 & VUSO & 158823,0 & 115752,0 \\
\hline 15 & KRAINA & 156702,0 & 120237,0 \\
\hline 16 & ALFA INSURANCE & 151713,4 & 65618,0 \\
\hline 17 & CREDO & 151641,0 & 128272,9 \\
\hline 18 & UNIVERSALNAYA & 147760,0 & 116885,0 \\
\hline 19 & PERSHA & 138641,0 & 134185,6 \\
\hline 20 & UPSK & 118901,7 & \\
\hline
\end{tabular}

Source: systematized by the authors (Forinsurer, 2018) 
payments. IC AXA Insurance, which occupies only the fifth place in the first rating with a $19.73 \%$ decrease in equity, nevertheless took the first position in the rating of insurance companies by the size of insurance payments. It should be noted that IC "Credo", which ranked 11 th in the first rating, with an increase in equity by $142.69 \%$, and in the rating of payments it took only 17th place, while almost 3 times increased the amount of insurance payments compared to 2016.

Thus, it can be concluded that there is no direct relationship between the increase in equity of the insurance company and the increase in the amount of insurance payments.

In some studies of the period from 2002 to 2015, to calculate the forecast of changes in the dynamics of insurance payments, the value of the indicator of the average annual growth rate showed that on average for each year of the study period, the growth rate of insurance payments for life insurance increased by 49.23\% (for life insurance); by $19.51 \%$ (for personal insurance); by $23.27 \%$ (for property insurance); by $18.83 \%$ (for liability insurance); and by $27.3 \%$ (for compulsory insurance).

Based on these studies, the forecast for insurance payments by types of insurance was calculated. According to the obtained results, the dynamics of insurance payments for life insurance and liability insurance have similar fluctuations to growth, the dynamics of insurance payments for personal insurance and property insurance also have a similar stable growth tendency, and the forecast of the dynamics of insurance payments for compulsory insurance shows a tendency to decrease (Ivanchenko, 2017).

\section{Problem aspects and directions for improving the insurance market}

Problems of overcoming the crisis in the insurance sector of Ukraine can be divided into external and internal ones. The first should include the high degree of dependence of the Ukrainian economy on the macroeconomic situation and the liquidity crisis of the banking system.

According to the report of the reinsurance company Swiss Re "Global Insurance Review and Outlook for 2017/2018", the US economic growth is projected at just over $2 \%$, taking into account inflation (in real terms) annually during 2017-2018. Growth in Europe, according to forecasts, - will be about 1\%, in Japan less than $1 \%$, and in China is expected to be about $6.5 \%$ (Swiss Re, 2016). As the economy of Ukraine mainly depends on the development of the economies of Europe and the US, the long-term forecast cannot reveal high growth rates at the moment.

Some authors note that in addition to the destabilizing factors inherent in the cyclical and transformational crises, additional destabilizing factors act in the
Ukrainian economy: 1) the annexation of Crimea and military actions in the Donbas, which caused people death, the refugee problem, the loss of a significant part of the country's production potential, and property of entrepreneurs and the population; 2) economic sanctions of Russia that had a negative influence on domestic exports and imports; 3) the inadequacy or absence of analysis by the government of the interaction of actions of different types of economic policies that have a stimulating (anti-crisis) or deterrent orientation, as well as economic policy mistakes that had negative economic consequences and social tension as a result; 4) the deficit of social capital in our society, increasing with the growth of distrust of the government (Cherednichenko, 2015). Simultaneous action of these three groups of factors that destabilize the domestic economy, in the fair opinion of G.A Cherednichenko, causes a negative synergistic effect - their joint impact on social and economic processes in the country is more intense and destructive than it could be under the action of one of the groups factors (Cherednichenko, 2015).

On the one hand, the crisis of many economic institutions (taxation, insurance, banking sector) was the result of the one-sided increase in developing in one direction, without taking into account the delay in increasing and active development in other areas of the economy. Indeed, with the well-functioning economic system, the network of banks is always serviced by numerous legal, accounting, insurance, and consulting companies. And the effectiveness of this interaction is greatly enhanced with the simultaneous improvement of all elements of the system.

On the other hand, the acceleration and delay in development can also be explained by the correct or wrong (incorrect) use of certain economic institutions. For example, using of law companies seems to be ineffective for delaying the resolution of a conflict with the help of legal institutions (seizure of property, maximum increase of the statutory period for consideration of the case, establishment of obstacles in the enforcement of judgments), and accounting and consulting companies for attempts to evade taxes.

Therefore, the solution of the problem of overcoming the crisis should be examined and solved simultaneously from various angles: the systematic development of all economic institutions and in-depth reforming at all levels of individual institutions.

Internal problems of overcoming the crisis of the insurance market include:

1) low level of capitalization of insurers and low quality of assets, which does not allow to ensure responsibility for large insured risks, which leads to reinsurance of their part abroad with an outflow of capital from Ukraine (Discovered, 2017);

2) lack of support of the insurance sector by the state during the crisis (in contrast to banking) and, in principle, the lack of the well-functioning planning 
mechanism in the practice of state regulation of the insurance sector of the economy;

3) lack of adequate formation of reserves of insurance companies and rules for calculating insurance reserves for controlling insurance risks;

4) lack of well-ordered statistics, which is necessary for actuarial calculations and actualization of the product supply;

5) unprofessional management of insurance companies; as the management of the majority of Ukrainian insurers is not able to timely and adequately respond to current and strategic challenges and risks;

6) insufficient using of investment opportunities by insurance companies over the lack of investment reliability. For example, in Ukraine, the level of coverage of potential risks is about $10 \%$, while in most developed countries this index is $90-95 \%$.

Today in Ukraine, to overcome these factors, they practice the absorption and capitalization of undeveloped and low-income insurance companies to reduce the amount of risk portfolios in the insurance market, as well as increase growth rates of certain types of insurance, improve the quality of services, and introduce new products (Discovered, 2017). However, these actions seem insufficient and do not solve the problem of overcoming the crisis as a whole.

\section{Aspects of reforming the regulatory basis of the insurance sector of the economy}

The presence of positive shifts in the development of the Ukrainian insurance market should be noted. In particular, since December 2016, 18 Ukrainian insurers offer the possibility of a direct settlement of MTPL (motor third party liability) contracts. If a car insured in one of these companies is damaged due to another member of the movement, its owner will be able to apply for payment to its insurer and not to the company of the culprit of the accident (if the culprit insurer participates in the direct settlement project). Now in Ukraine, the average repayment period for a direct settlement is 24 days, for the MTPL (motor third party liability) market as a whole - more than 100 (Delo.ua, 2018) (according to Ukrainian legislation not more than 90 days). However, to date, not all companies that offer MTPL (motor third party liability) contracts in Ukraine participate in this project, and this disadvantage is sensible to eliminate in the near future.

In addition, on $02 / 02 / 2017$, the National Commission, which implemented state regulation in the sphere of financial services markets, adopted an order that allows the conclusion of MTPL electronic contracts. It seems to be promising to extend this order to other types of insurance. This will cut down expenses for the conclusion of the agreement because the client will be able to track the appearance of his contract in the insurance company's database and minimize the cases of abuse by the client in cases where the client conceal information about similar insurance contracts that he signed with other insurance companies.

Some promising perspective for Ukraine types of insurance require an early detailed and clear normative regulation, among which can be named:

- insurance of agricultural producers, since the production of agricultural products at the moment in Ukraine is the most payback type of business activity;

- insurance of liability of small boats; in Ukraine, the quantity of large vessels is insignificant, however, there are a lot of yachts, boats, and other small vessels, whose owners are interested in developing of this type of insurance;

- insurance of cyber-risks, because IT-technologies in recent years have penetrated into all spheres of activity of the population and business entities.

\section{Conclusions}

Overcoming the crisis of the insurance sector of Ukraine requires the development of measures of economic and legal nature. In particular, the state should develop a clear and legible mechanism for planning the insurance sector of the economy, including the creation of well-ordered statistics, which is necessary for actuarial calculations and actualization of the goods supply, clear normative regulation of the most promising types of insurance for Ukraine.

In addition, the implementation of some actions depends directly on the activity of insurance companies. It is necessary to increase the level of capitalization of insurers, to develop rules for calculating insurance reserves for their adequate formation, to increase the professionalism of management of insurance companies, to use investment opportunities more actively.

Since the development of actions to minimize and eliminate the consequences of the global economic crisis has become a supranational task, the proposals mentioned above can be used with taking into account the specifics of economic development and the condition of the insurance sector of the economy also in other states.

\section{References:}

Delo.ua. (2018). Chto proiskhodit na strakhovom rynke Ukrainy [What is it all about the insurance market of Ukraine] (unpublished). Retrieved from: https://delo.ua/econonomyandpoliticsinukraine/chto-proishodit-nastrahovom-rynke-ukrainy-338019/ (in Russian)

Doing Business (2017). Retrieved from: http://doingbusiness.org 
Forinsurer. (2018). Reyting strakhovykh kompaniy Ukrainy [The rating of insurance companies in Ukraine] (unpublished). Retrieved from: https://forinsurer.com/ratings/nonlife (in Russian)

Forinsurer. (2018). Reyting strakhovykh kompaniy po razmeru sobstvennogo kapitala za 2017 god [The rating of insurance companies by the amount of the ownership capital for 2017] (unpublished). Retrieved from: https://forinsurer.com/ratings/nonlife/17/12/2 (in Russian)

Ivanchenko O. (2017). Statystychnyj analiz strakhovogho rynku ta vyplat za vydamy strakhuvannja v Ukrajini za 2002-2015 roky [The statistical analysis of insurance market and insurance benefits by the insurance classes in Ukraine for 2002-2015]. Retrieved from: http://phm.kspu.kr.ua/images/konf ftn/ 2017/s8/\%D0\%86\%D0\%B2\%D0\%B0\%D0\%BD\%D1\%87\%D0\%B5\%D0\%BD\%D0\%BA\%D0\%BE \%D0\%9E.pdf (in Ukrainian)

Swiss Re. (2016). Global insurance review and outlook for 2017/2018. Retrieved from: https://forinsurer.com/ files/file00596.pdf

Cherednichenko G.A. (2015). Gosudarstvennoe antikrizisnoe regulirovanie ekonomiki i ego sovremennye tendentsii [The state anti-recessionary regulation of economy and its modern trends]. Institutional framework for the functioning of the economy in the context of transformation: collection of scientific articles. Canada: Publishing house «BREEZE», vol. 1, pp. 79-86. (in Russian)

Discovered (2017). Osnovnye problemy strakhovogo rynka Ukrainy [The key problems of the insurance market of Ukraine] (unpublished). Retrieved from: http://discovered.com.ua/insurance/osnovnye-problemy-straxovogorynka-ukrainy/ (in Russian) 